\title{
Contribution of Paddy Production to Household Income in Farmer-Managed Irrigation Scheme Communities in Iringa Rural and Kilombero Districts, Tanzania
}

Devotha B. Mosha ${ }^{1}$, Paul Vedeld ${ }^{2}$, Josiah Z. Katani ${ }^{3}$, George. C. Kajembe ${ }^{4}$ and Andrew K.P.R. Tarimo ${ }^{5}$

${ }^{1}$ Institute of Continuing Education, Sokoine University of Agriculture, P.O. Box 3044, Morogoro, Tanzania. E-mail: devotha.kilave@gmail.com

${ }^{2}$ Norwegian University of Life Sciences. P.O. Box 5003, N-1432, Ås, Norway.

E-mail: pal.vedeld@ @mbu.no

${ }^{3}$ Department of Forest Resources Assessment and Management, Sokoine University of Agriculture, P.O. Box 3013, Morogoro, Tanzania. E-mail: josiahkatani@yahoo.com

${ }^{4}$ Department of Forest Resources Assessment and Management, Sokoine University of Agriculture, P.O. Box 3013, Morogoro, Tanzania. E-mail: kajembegc@yahoo.com

5Department of Engineering Sciences and Technologies, Sokoine University of Agriculture.

P.O. Box 3003, Morogoro, Tanzania. andrewtarimo2@yahoo.co.uk

Devotha B. Mosha (Corresponding author)

Institute of Continuing Education, Sokoine University of Agriculture, P.O. Box 3044, Morogoro, Tanzania. E-mail: devotha.kilave@gmail.com

Received: January 23, 2018

doi:10.5296/jas.v6i2.13147
Accepted: May 9, 2018

URL: https://doi.org/10.5296/jas.v6i2.13147 


\section{Abstract}

Irrigation reduces risks involved in agriculture and enables farming throughout the year. Improved irrigation systems enhance access to irrigation water. However, most smallholder farmers continue to use traditional irrigation schemes as if the difference in water use and crop yields between the two is insignificant. It seems essential to assess the paddy crop yield difference and its contribution to household incomes between traditional and semi-improved Farmer-Managed Irrigation Schemes (FMISs) in Iringa Rural and Kilombero districts in Tanzania. A cross-sectional research design was used in this study involving 48 key informants and 172 randomly selected households. Household survey using a structured questionnaire was the major method for data collection. Data from focus group discussions and key informants supplemented the information collected using household survey. The data were analyzed using Statistical Product and Service Solutions (SPSS). Results indicate that yield of paddy was higher in semi-improved schemes (2.5-3.6 tons/ha) compared to traditional irrigation schemes (2.2-2.9 tons/ha). This was attributed to the presence of improved water intake structures and existence of main canals, which facilitated an improved water supply to the irrigation fields. In spite of the poor and incomplete irrigation infrastructure, the paddy production contributed very significantly (73-80\%) to the total annual household income of smallholder irrigators and somewhat more in the improved system than the traditional system. Other income sources are quite marginal in the study areas. The study recommends that the government should invest in irrigation infrastructure development to increase irrigation water use efficiency and increase agricultural values added.

Keywords: economic analysis, paddy, income, irrigation, famer-managed irrigation scheme, Tanzania

\section{Introduction}

Agriculture is critical to the Tanzanian economy, accounting for $25.8 \%$ of GDP and $80 \%$ of total employment. It also provides raw materials to her agricultural industrial sector. The country is endowed with a total area of 94.5 million hectares (ha), out of which 44 million (ha) is arable land suitable for agricultural production. Forest land covers 48.1 million ha and the area under fresh water bodies is approximately 62000 square kilometers (Ministry of Natural Resources and Tourism (MNRT), 2015). Only 23\% of the arable land is currently under cultivation (United Republic of Tanzania (URT), 2012). Factors that contributed to this small percent include soil erosion, leaching and drought proneness (URT, 2013). Low infrastructure and capital investments are also important factors in this context (Bjornlund et al., 2016; Mdemu et al., 2017). Nonetheless, agriculture remains the most important sector in the country. It produces over $80 \%$ of the food consumed locally as well as accounting for $74.5 \%$ of agriculture's share of the GDP (Isinika et al., 2016).

Crop production is mainly rain-fed, and which is currently threatened by several risk factors including climate change and progressive land degradation caused by human activities. This poses serious challenges to both rain-fed and irrigated agriculture. This calls for specific interventions in order to increase and sustain land productivity. In Tanzania, 29.8 million ha 
of arable land is potential for irrigation. However, currently only about 1.5 percent is under irrigation (URT, 2013). Of these, 64\% is under Farmer-Managed Irrigation Schemes (FMIS) while 36\% is Estates under Agency-Managed Irrigation Schemes (AMIS) (URT, 2011).

The commonly used yardsticks for defining FMISs include the status of irrigation infrastructures (e.g. design and construction status) and land levelling. In this context, Tanzania's FMIS have been categorized as either traditional or improved (modern) (Agriculture Water Management (AWM), 2010). The former involves the use of simple unlined canals, and the latter involves schemes with improved irrigation structures (headwork structures designed and constructed irrigation and drainage canals as well as land leveling). However, there is a third category; farmers do call it 'a semi-improved scheme. These are schemes with incomplete irrigation systems. In this case, the intakes are properly designed and constructed, and sometimes the main canals are also designed and constructed. The main canals may even be lined while the rest irrigation systems remain traditional in every aspect. The FMISs serve as a means to ensure food security and are essential for providing employment opportunities for landless poor (You et al., 2010). Although crop productivity gains from irrigation remain contested (Fanadzo et al., 2010), they provide insurance for farmers against drought and play an integral role in a transition from subsistence to commercial farming. Over the past 40 years, the FMISs have been a development focus for rural household livelihood improvement strategies (Sinyolo et al., 2014). Paddy is the main crop grown in these FMISs, and its value has increased rapidly throughout Tanzania. It is now the second most important staple food crop after maize and is both a food and a commercial crop (National Bureau of Statistics (NBS), 2008). In a broader economic context, paddy is viewed as a cash crop due to its export potential and its contribution to national food security.

In the 1990s, Tanzanian government embarked on irrigation management transfer from central government to farmers through the FMIS. The process aimed to empower local irrigators through increasing their capacity to own, control and manage their own irrigation systems (URT, 2011). As a result, operation and maintenance of the irrigation systems were improved which led to higher efficiency and a commercialization of paddy crop. The commercialization was supported by the Government and other non-governmental organization agencies such as the International Development Association (IDA) through various programmes including: the Agricultural Sector Development Programme (ASDP), the Participatory Agricultural Development and Empowerment Project (PADEP), the River Basin Management and Smallholder Improvement Project (RNM SSIP) and the Tanzania Social Action Fund (TASAF) (URT, 2013). The objective of the Government and the development partners is to increase productivity and farm income by improving farmers' use of and access to irrigation water, agricultural knowledge and technologies.

Investment in irrigation infrastructure has improved crop productivity in both improved and semi-improved farmer-managed small-scale irrigation in most parts of Tanzania. A vivid example is Lower-Moshi (modern) irrigation scheme where paddy yield has increased from 1.4 to 2.5 tons per ha (Kisawike, 2008). Arguably, farmers in the traditional schemes have adopted some knowledge and technological aspects of improved irrigated agriculture (Mosha et al., 2016). However, there is scant information on the yield differences between improved 
and traditional irrigation schemes. To motivate smallholder irrigators to invest in irrigation systems improvement, it is necessary to examine and understand the contribution of paddy crop from both traditional and semi- improved FMISs. This article highlights the contribution of paddy to household income and how the yields compare between the emerging semi-improved and traditional schemes based on results from four case studies of Mlenge, Mkombozi, Mkula and MAKI FMISs in Tanzania. The article further discusses socio-economic parameters of paddy productivity and its relation to income at the household level. This implicitly indicates that the findings from the study may motivate smallholder irrigators to invest in irrigation infrastructure development for the objective to transform subsistence farming into commercial agriculture.

\section{Methodology}

\subsection{Study Areas}

In consultation with District officials, four schemes were selected to cover a wider but not exhaustive range of FMISs. The schemes selected were: Mlenge (Itunundu village), Mkombozi (Mboliboli village) in Iringa Rural district, and Mkula (Mkula village) and MAKI (Magombera village) in Kilombero district.

Mlenge has an area of about 4,217 ha with a permanent intake structure. The main canal is 45 $\mathrm{km}$ long, out of which $1.6 \mathrm{~km}$ is lined with concrete while the rest, together with secondary and tertiary canals, are unlined.

Mkula has a total of 254 ha, but only 100 ha were under irrigation in the 2013/2014 cropping season. It has a permanent intake made of concrete and a main canal of about $15 \mathrm{~km}$ long out of which $4.8 \mathrm{~km}$ is lined with concrete, while the rest were unlined.

Mkombozi and MAKI are traditional irrigation schemes with a total of 3000 and 320 ha of irrigated land, respectively. In these traditional schemes, farmers have constructed temporary intakes using logs, tree branches, stones and bags full of earth material across the rivers to divert water into their respective main canals. The technical efficiency of such simple technology is quite low (Adams et al., 1994). Irrigators or members of these irrigation schemes are villagers in nearby villages and some come from various regions in Tanzania. Irrigation water for Mlenge and Mkombozi schemes is extracted from Little Ruaha River, and this is contrary to Mkula and MAKI schemes where irrigation water is from three different sources namely Mkula, Sonjo and Rufiji rivers. In these schemes irrigation water is extracted by gravity system, and is distributed to the fields using secondary and tertiary canals.

The Iringa Rural district lies between latitudes $8^{\circ} 20^{\prime}$ and $8^{\circ} 30^{\prime} \mathrm{S}$ and longitudes $35^{\circ} 30^{\prime}$ and $35^{\circ} 50^{\prime} \mathrm{E}$ and constitute a total of 2057600 hectares (ha) (Iringa District Council, 2013). The climate varies with altitude and is closely associated with two distinctive landscape zones midland and lowland. The midland zone has an annual rainfall ranging from 1000 to 1600 $\mathrm{mm}$ and a day temperature from 15 to $20^{\circ} \mathrm{C}$, while the lowland zone (the northern part) where the study villages are located has an average rainfall of $500 \mathrm{~mm}$ and a temperature of $20-$ $25^{\circ} \mathrm{C}$. In 2012 the population of Iringa Rural district was 254032 including 123243 males and 130,789 females (NBS, 2013). 
Kilombero district lies between latitudes $70^{\circ} 40^{\prime}$ and $9^{\circ} 21^{\prime} \mathrm{S}$ and between longitudes $35^{\circ} 20^{\prime}$ and $37^{\circ} 48^{\prime} \mathrm{E}$ and has a size of $14918 \mathrm{~km}^{2}$. Most of the district's area lies along Kilombero valley (wetland) which supports both small and large scale farming. The district has 17606 ha of irrigation (Kilombero District Council, 2013). The rainfall in the district is bimodal and ranges from 1200 to $1600 \mathrm{~mm}$ with one short and one long rainy season from November to February and March to May, respectively. The dry season is from June to October, and the temperature varies from $25^{\circ} \mathrm{C}$ to $28^{\circ} \mathrm{C}$. In 2012 the population of Kilombero district was 407,880 including 202789 males and 205091 females (NBS, 2013).

\subsection{Research Design, Sampling Procedure and Sample size}

The study used a cross-section research design, which involves collection of data from different respondents at one point of time and from various data sources for triangulation purpose. This design was useful to reduce biases and increase the reliability of the data collected (Creswell, 2014). A multistage purposeful sampling procedure was applied to select divisions, wards and villages. The first stage was the selection of one division and then one ward in each district based on the presence of FMISs. The second stage involved purposive selection of two FMISs from each ward, making a total of four FMISs. The third stage involved purposive selection of one village in each selected FMIS, making two villages per district. Selection was based on the two schemes in each village being located in the same agro-climatic ecological zone (one having a traditional and the other one having a semi-improved FMIS) and having a common major irrigated crop. Mlenge and Mkula are semi-improved while the other two are traditional schemes. The last stage involved random selection of 172 household heads from village household registers as sampling frames (Table 1). The sample size was consistently greater than $5 \%$ of the total population in each case - a minimum size to ensure meaningful statistical inference (Boyd et al., 1981).

Table 1: Household numbers and sampling intensity in the study areas, Iringa and Kilombero districts, Tanzania (2013)

\begin{tabular}{|c|c|c|c|c|c|c|}
\hline District & Village & $\begin{array}{l}\text { Households } \\
\text { in the } \\
\text { village }\end{array}$ & $\begin{array}{l}\text { Scheme } \\
\text { name }\end{array}$ & $\begin{array}{l}\text { Households } \\
\text { in the FMIS }\end{array}$ & $\begin{array}{l}\text { Sample } \\
\text { size }\end{array}$ & $\begin{array}{l}\text { Sampling } \\
\text { intensity } \\
(\%)\end{array}$ \\
\hline Iringa & Mboliboli & 1300 & Mkombozi & 930 & 60 & 7 \\
\hline Rural & Itunundu & 1610 & Mlenge & 854 & 50 & 6 \\
\hline \multirow[t]{2}{*}{ Kilombero } & Mkula & 322 & Mkula & 322 & 32 & 10 \\
\hline & Magombera & 294 & MAKI & 294 & 30 & 10 \\
\hline Total & & 3526 & & 2400 & 172 & 7 \\
\hline
\end{tabular}

Source: Survey Data (2013) 


\subsection{Data Collection Methods}

A range of data were collected over a two-year period from 2013 to 2014. First, a structured questionnaire was administered through face to face interviews of 172 farm households aimed to elicit household information including bio-data, farming systems, production costs, crop yield and quantity consumed, stored and sold. The questionnaire was piloted by interviewing fifteen household heads using it in Msolwa Ujamaa village and revised based on shortcomings observed. Focus Group Discussions (FGDs) were conducted in each study village; each of them involved a panel of 12 people who were purposively chosen based on their experience with the research topic. The composition of the groups in terms of sex, age and wealth was taken into account, and active participation of both men and women was encouraged. FGDs aimed at evaluating the progress of irrigation schemes, paddy production and marketing, and sources of household income. The discussions also aimed at triangulation and clarification of doubtful information reported during the household survey. Discussions were recorded using note books and a digital recorder to enable precise transcriptions. Data collection also included observations by researchers and two assistant researchers regularly visiting schemes, irrigators' homesteads, and participation in meetings and markets. Direct observations of farmers' fields provided understanding and verification on irrigation structures, farm size, types of crops grown, and units of measurement.

\subsection{Data Analysis}

Qualitative data were analyzed using content analysis that helped to reduce and cluster recorded information into smaller meaningful units based on themes, trends, frequently cited and strongly held opinions. The qualitative data were used to support the discussion of the quantitative findings. Quantitative data were coded, processed, and descriptively analyzed using Statistical Product and Service Solutions (SPSS). The survey data were used to produce distribution of response tables and to support the development of typologies. Cross-tabulation and simple computation allowed estimation of the financial contribution of irrigated crops to gross and net household incomes of the 2012/2013 production year. Estimated net incomes for each livelihood activity were calculated as gross income minus production costs. Costs were all expenditures incurred by a household during the process of crop cultivation. These included inputs, transportation costs, water fees and other related costs. In this study fixed production costs are owned land, irrigation infrastructure, and family labour, whereas variable costs included agricultural inputs, transport, land preparation, harvesting, transportation and processing costs. In all net income calculations, family labour was excluded because the respondents were unable to recall, so only the costs of hired labour were included. The average price of peak selling period, which ranged between June and December, was established and used in calculations of gross income.

An independent samples t-test was used to examine the variation in mean yields and income levels of farmers engaged in traditional and semi-improved FMISs. As explained by Pallant (2007), the independent t-test is suitable to test the hypothesis for two samples with different sample sizes coming from different data sets. The income outputs were based on the cost and price of 2013 at farm-gate. Equation (1) was adopted for calculation of net income of each 
livelihood activity per household, while Equation (2) sums up all incomes in a particular household.

$\pi=Y P_{y}-\sum_{i}^{n} C_{i}$ Equation 1

Where,

$\pi=$ Net return of livelihood activity;

$Y=$ Total quantities of product (paddy, sugarcane, maize, sorghum);

$P_{y}=$ Prices of product (paddy, vegetables, rain-fed crops, sugarcane, livestock \& forest product);

$C_{i}=$ Estimated cost of production (e.g. in case of paddy - hired labour, power tiller, seedling, fertilizer, insecticide, harvesting and transportation costs).

$Y_{t}=\sum_{i=1}^{n}\left(Y_{i p}+Y_{h}+Y_{s}+Y_{o}+Y_{f+}+Y_{1+}+Y_{1}\right)$

Where,

$Y_{t}=$ Total household income;

$Y_{i p}=$ Net income from irrigated paddy crop;

$Y_{h}=$ Net income from vegetable crops;

$Y_{s}=$ Net income from sugar cane crop;

$Y_{o}=$ Net income from other rain-fed crops;

$Y_{l}=$ Net income from livestock;

$Y_{f}=$ Net income from forest products;

$Y_{l}=$ Net income from labour and land rented.

Multiple Linear Regression Models were used to analyze factors influencing paddy yield and household income. Before running the model, ten independent variables and the dependent variable were checked for normality by computing their normal curves, which were then checked visually to find whether they had normal distributions (Pallant, 2007). Area under cultivation and incomes per household had no normal distribution; hence it was transformed to the $\log$ base ten values. The independent variables' correlations were examined to check for multicollinearity. The tolerance values of co-linearity greater than 0.1 and Variance Inflation Factor (VIF) values of co-linearity less than 10, mean that there was no multicollinearity. Duration in irrigation farming had a VIF of above 10, implying that it was correlated with farming experience. Therefore, it was dropped out from the list of independent variables. The multiple linear regression model was specified as follows:

$\mathrm{Y}_{1} / \mathrm{Y}_{2}=\mathrm{a}+\beta_{1} \mathrm{X}_{1+} \beta_{2} \mathrm{X}_{2+} \beta_{3} \mathrm{X}_{3}+\ldots . \mathrm{B}_{9} \mathrm{X}_{9+\mathrm{e}}$

Where,

$\mathrm{Y}_{1} \quad=\quad$ Total paddy yield;

$\mathrm{Y}_{2}=$ Total household income

$\beta_{1}-\beta_{9}=$ Regression coefficients; 
e $\quad=$ Error term representing a proportion of the variance in the dependent variable that was unexplained by the regression equation;

$\mathrm{X}_{1} \quad=$ Age of household head (measured in years);

$\mathrm{X}_{2} \quad=$ Sex of household head (SEX);

$\mathrm{X}_{3} \quad=$ Education level of the household heads (years of schooling);

$\mathrm{X}_{4} \quad=$ Farm size (measured in hectares);

$\mathrm{X}_{5} \quad=$ Household size (number of household members),

$\mathrm{X}_{6} \quad=$ Adequate water access $(1=$ Yes; $0=\mathrm{No})$;

$\mathrm{X}_{7} \quad=$ Quantity of fertilizer used (kg per ha)

$\mathrm{X}_{8} \quad=$ Farm implements used in cultivations (value of hired);

$\mathrm{X}_{9} \quad=$ Farming experience (measured in years).

\section{Results and Discussion}

\subsection{Demographics and Characteristics of Irrigators}

The respondents' major socio-economic characteristics are shown in the Table 1. More than three-fifths $(63 \%)$ of the household heads were in the age group of $20-45$ years. The mean age of household heads was 39 years, implying that the majority of irrigators in the study areas were in active age group, and probably capable of doing most of the farming activities. The active age observed in this study is similar to other observations in rural Tanzania. For example, Tenge et al. (2015) reported that $71 \%$ of irrigators in Mvomero district in Morogoro region were in the age group of 20-48 years, who are active in farming activities.

A high proportion $(82 \%)$ of the farm household heads had attained primary education while $11 \%$ did not have formal education, and $7 \%$ had education beyond primary school. Education levels can influence individuals' or households' choice of a livelihood strategy (Urassa, 2015) as well as influence adoption of new agricultural technologies (Mkula, FGD). In addition, Chazovachii (2012) pointed out that an increase in an individual's years of schooling/education is expected to increase one's range of work-related skills and hence the ability to acquire new skills.

The average farming experiences varied among the case studies with 28, 26, 19 and 17 years in Mkula, Mlenge, Mkombozi and MAKI FMISs, respectively. In this case, farm household heads in Mkula and Mlenge, which are semi-improved FMISs, have longer and substantial farming experience. According to FGD discussants, the majority of irrigators had more experience and competence in irrigation farming because irrigation was their main livelihood activity since their childhood (Mlenge, FGD). This explicitly clarifies that in arid and semi-arid areas of Tanzania, irrigation is given high priority as a strategy to food security and poverty alleviation. This is even emphasized in many Tanzania's vision documents including the National Irrigation Policy (URT, 2010) and the Second National Strategy of Growth and Reduction of Poverty (URT, 2010). Similarly, the current Government initiatives, which include the Southern Agricultural Growth Corridor and the Big Results Now (URT, 2013), place irrigation at the core of achieving food security and poverty reduction among poor households. 
More than four-fifths of the household heads (85\%) were male (Table 1). According to FGDs discussants, men typically dominate in the irrigation scheme, and of course they are the ones who dominate in household decision-making, particularly on acreage put under irrigation, use of mechanization and the marketing of agricultural produce. Similarly, male dominance is reported in other places by Fanadzo (2012) and Tenge et al. (2015). The dominance of men is a possible reflection a typical patrilineal society in Tanzania and of traditional African values where the male is recognized as the head of household and often in particular in charge of technical and capital demanding innovations (Tenge et al. 2015). Likewise, Urassa (2015) pointed out that land ownership is mainly a male right as a result of the highly entrenched patriarchal system.

Both men and women participate in the majority of farm work. However, men are responsible for spraying pesticides, applying fertilizers, transporting inputs to farms and produce from farms to homestead and follow-up of water extraction to the fields at night in particular. On the other hand, the women are responsible for transplanting, weeding, harvesting and threshing. Farmers reported that high demand for labour was from December to March. The reason for the high labour peak during those months was attributed to both rain-fed and irrigated plots being under cultivation.

The mean irrigation area varied across the schemes (Table 2). The land size was significantly greater in Iringa Rural than in Kilombero district. According to focus group discussion and key informant interviews this significant difference was caused by three factors: First, there is and there has been more land available in Iringa than in Kilombero district. Fundamentally, this could be because land in Kilombero is more valuable, not only agronomically, but also in terms of better infrastructure and proximity to market places and generally richer ecosystem services of various kinds including being biodiversity hotspots. This is then institutionally reflected in more protected areas and national parks, and more commercial interests in farming (and plantations), more people moving in and in higher population growth, higher prices of land, etc. in Kilombero. These important factors may increase (structural) land scarcity and hence demand for land. Second, a traditional system of land inheritance through sub-division of land to children has over time in general reduced land size since the same land portion is divided to sons of one generation to another, which seems to be more practised in Kilombero than in Iringa. Third, land scarcity is related to when and how land in the irrigation schemes was distributed and how much land was developed in the schemes. For instance, Mkula scheme was established in 1970, and land allocated was little compared to other schemes. 


\section{Macrothink}

Journal of Agricultural Studies

ISSN 2166-0379

2018, Vol. 6, No. 2

Table 2. Demographics and characteristics of respondents in the irrigation schemes in Iringa Rural and Kilombero districts, Tanzania

\begin{tabular}{|c|c|c|c|c|c|}
\hline \multirow[t]{2}{*}{ Variable } & \multicolumn{2}{|c|}{ Iringa district } & \multicolumn{2}{|c|}{ Kilombero district } & \multirow[b]{2}{*}{$\begin{array}{l}\text { Total } \\
\text { sample }\end{array}$} \\
\hline & $\begin{array}{l}\text { Mkombozi } \\
\text { TS }\end{array}$ & $\begin{array}{l}\text { Mlenge } \\
\text { SIS }\end{array}$ & $\begin{array}{l}\text { Mkula } \\
\text { SIS }\end{array}$ & MAKI TS & \\
\hline Sample size (n) & 60 & 50 & 32 & 30 & 172 \\
\hline \multicolumn{6}{|l|}{ Age group (\%) } \\
\hline $20-45$ & 68 & 62 & 53 & 67 & 63 \\
\hline $46-55$ & 15 & 22 & 25 & 23 & 21 \\
\hline $55+$ & 17 & 16 & 22 & 10 & 16 \\
\hline \multicolumn{6}{|l|}{ Education (\%) } \\
\hline No formal schooling & 10 & 8 & 5 & 20 & 11 \\
\hline Primary school & 86 & 82 & 88 & 75 & 82 \\
\hline Secondary school & 2 & 8 & 7 & 5 & 6 \\
\hline Professional/college & 2 & 2 & 0 & 0 & 1 \\
\hline \multicolumn{6}{|l|}{$\begin{array}{l}\text { Sex of household head } \\
(\%)\end{array}$} \\
\hline Male & 83 & 85 & 86 & 87 & 85 \\
\hline Female & 17 & 15 & 14 & 13 & 15 \\
\hline \multicolumn{6}{|l|}{ Marital status (\%) } \\
\hline Married & 76 & 80 & 79 & 90 & 80 \\
\hline Single & 9 & 8 & 9 & 3 & 7 \\
\hline Widowed & 15 & 12 & 12 & 7 & 13 \\
\hline $\begin{array}{l}\text { Mean years of } \\
\text { engaging in irrigation }\end{array}$ & 19 & 29 & 28 & 17 & 23.3 \\
\hline Mean household size & 5.2 & 6.5 & 5.4 & 5.3 & 5.6 \\
\hline $\begin{array}{l}\text { Mean irrigation area } \\
\text { (ha) }\end{array}$ & 1.9 & 1.2 & 0.3 & 0.8 & 0.8 \\
\hline Mean land owned (ha) & 1.3 & 2.3 & 0.9 & 1.02 & 1.1 \\
\hline
\end{tabular}

Note: TS = Traditional Scheme; SIS = Semi-improved Scheme

Source: Survey Data (2013)

\subsection{Economic Activities and Main Crops Grown}

More than $80 \%$ of the populations rely on agricultural crop production, while the rest depend on small scale livestock keeping, fishing and businesses. Paddy is the main crop grown under irrigation, and it is produced for both own consumption and for sale both in local and other big market places. Other irrigated crops particularly grown in the dry season includes tomatoes, vegetables, egg plants, water melons and cucumbers. However, these crops were produced at small-scale, and in most cases for household consumption or for selling within their villages. Many farmers of Mkula and Magombera villages grew sugarcane as 
out-growers for the Kilombero Sugar Estate. During FGDs, many out-growers claimed that, due to the monopolistic nature of the Estate, the price of sugar cane paid to the small-scale producers had gone down drastically, a thing which caused the farmers to reduce if not to stoping investing in their production. Banana was also a significant commercial crop in Kilombero district, grown around homesteads and maintained over seasons.

\subsection{Production and Paddy yield variations by type of scheme and location}

Qualitative results revealed that, since 2004, the yield of paddy per ha had increased in both Iringa and Kilombero districts. On average the yield had increased from 1.7 (2004) to 3.5 tonnes $\mathrm{ha}^{-1}$ (2014) in Kilombero, and from 1.9 (2004) to 3.6 tonnes ha ${ }^{-1}$ (2014) in Iringa district. The increase in yield of paddy is characterized by changing a range of paddy management practices, including: (a) adoption of agronomical practices including early or timely transplanting of seedlings, (b) planting one or two seedlings , (c) sparse planting in checkrows, and (d) the use of modern farm implements. No new seed variety was required in Iringa Rural district. This was different from Kilombero district where organic fertilizers were used to boost productivity. It was observed that the majority of farmers used planters, power tillers and herbicides, which improved farm management and therefore enhanced crop growth and performance. In both districts, there has been a shift in rice planting method from dry soil broadcast to transplanting. In Kilombero study cases, this new planting system, coupled with increases in application of fertilizers and chemicals, provides high yield per ha. However, this technique works better in a well-levelled field and with a good water control system to drain out water before broadcasting rice in order to increase the water level to the appropriate height of the growing plants. Hence, it has been adopted by over $95 \%$ of the farmers in semi-improved irrigation schemes. In traditional irrigation schemes without land levelling, transplanting can be, and was, practised in a more limited areas, depending on the degree of water controllability as acknowledged by $70 \%$ of the respondents.

Referring to Table 3, the mean yield of paddy in Mlenge semi-improved and Mkombozi traditional schemes (Iringa Rural) were 3.6 and 2.9 tonnes ha $^{-1}$ respectively compared to 2.7 and 2.5 tonnes ha $^{-1}$ in Mkula semi-improved and MAKI traditional schemes respectively (Kilombero). The difference in means of paddy yield were statistically significant only for the Iringa case studies. The mean yields reported are slightly higher in semi-improved schemes compared to traditional schemes (some $9 \%$ and $20 \%$ in the two districts). This observation was due to the fact that in semi-improved irrigation schemes, access to irrigation water was better than in traditional irrigation schemes because some irrigation systems were improved hence smoothly facilitated water flows to the fields. The mean yields reported in both study districts are a bit higher than what was reported by Mwatawala et al. (2016), who reported a yield of 1.6 tonnes $\mathrm{ha}^{-1}$. Likewise, the maximum mean yield of 2.9 tons/ha was generally the same as reported by Mongkolsmai and Rosegrant (1995) in Thailand. In their study, irrigated paddy yielded a total of 2.9 and 3.9 tons/ha in improved land consolidation in wet-season and dry-season respectively. The observed difference in Kilombero and Iringa districts depending on the availability of water from the river and by the way the schemes are located. For example, referring to the location, the upland (Mlenge scheme) received water first before the down land (Mkombozi scheme). Rationally, paddy which received good amount of water at 
growing stage performed better and therefore tends to yielded more (Wim, 2012).

In addition, there is an increase in yield because farmers in the area put a lot of efforts on irrigated paddy production because of risks associated with rain-fed agriculture, currently affected by climate change and variability. The rapidly changing climate has unsettled seasonal cycles and altered natural water-supply systems across Tanzania as elsewhere in Africa. New rainfall patterns have led to uncertainties in the onset of the farming season, resulting in late harvests, harvest failure and, ultimately, food shortages (Kadigi et al., 2007).

The frequency of floods and landslides is also on the increase. As stated earlier, farmers cultivate in the schemes for two main reasons: i) to sell harvest for income generation and ii) to satisfy household food requirements. Evidence consistently shows that irrigated agricultural production is high in arid and semi-arid areas because of change in rainfall pattern (Minow, 1997). Irrigation has therefore become an effective strategy to ensure food security and reducing poverty in the dried regions of Central Tanzania, Usangu Plains and in some parts in Arusha and Kilimanjaro regions. This could also be in response to the Government policy of promoting irrigation in the drier areas, which is increasingly being implemented in the country.

Table 3. Comparing paddy crop yields (tons/ha) between traditional and semi-improved FMISs in Kilombero and Iringa districts, Tanzania

\begin{tabular}{|c|c|c|c|c|c|}
\hline \multicolumn{6}{|l|}{ Iringa Rural District } \\
\hline Variables & No of cases & Mean & STD & $\begin{array}{l}\mathrm{t}- \\
\text { value }\end{array}$ & P-value \\
\hline Mlenge Semi-Improved FMIS & 50 & 3.6 & 0.72 & 2.409 & $0.016^{*}$ \\
\hline Mkombozi Traditional FMIS & 60 & 2.9 & 1.31 & & \\
\hline \multicolumn{6}{|l|}{ Kilombero District } \\
\hline Variables & No of cases & Mean & STD & $\begin{array}{l}\mathrm{t}- \\
\text { value }\end{array}$ & P-value \\
\hline Mkula Semi-Improved FMIS & 32 & 2.7 & 0.88 & 1.643 & $0.51 \mathrm{~ns}$ \\
\hline MAKI Traditional FMIS & 30 & 2.5 & 0.15 & & \\
\hline Between sites & No of cases & Mean & STD & $\begin{array}{l}\text { t- } \\
\text { value }\end{array}$ & P-value \\
\hline Kilombero District & 62 & 2.6 & 0.71 & 1.643 & $0.03 *$ \\
\hline Iringa Rural District & 110 & 3.3 & 0.88 & & \\
\hline
\end{tabular}

In tonnes/ha; Ns $=$ Not statistically significant and $*$ significant at $\mathrm{p}<0.005$.

Source: Survey Data (2013)

\subsection{Contribution of paddy and other livelihood activities to household income}

The results in Table 4 reveal the total household income accrued from paddy, rain-fed crops, livestock, forest products and other sources. The study found that income of smallholder famers in irrigation schemes depended more on irrigated paddy. Paddy crop contributed to 


\section{NI Macrothink}

Journal of Agricultural Studies

ISSN 2166-0379

2018, Vol. 6, No. 2

household income of Tanzanian Shillings (TZS) 1302 200; 1102 300; 940199 and 801980 for Mlenge, Mkombozi, Mkula and MAKI irrigation schemes respectively, which are highest amounts in all cases studied (Table 4). District-wise, paddy crop contributed much of the net household income accounting for $80 \%$ and $73 \%$ of the average total household income in Iringa and Kilombero districts respectively. The study also identified that sugarcane production (15\%) and off-farm activities $(9 \%)$ were the second contributors to household income in Kilombero and Iringa districts respectively. Other economic activities such as livestock keeping, rain-fed crops, forest products and horticultural crops had very minimum contribution to household income in Iringa and Kilombero districts. In respect to livestock keeping, farmers highlighted three main constraints impeding livestock keeping and/or management in Mkula and Magombera villages. First, the study villages were surrounded by crop fields, Udzungwa Mountain National Park and Selous Game Reserve, which implies low access to grazing land. Secondly, the majority of the inhabitants (Wambunga, Wandamba, Wapogoro, Wandewa and Wang'indo) are traditionally not livestock keepers. In-migrant ethnic groups such as Wabena, Wangoni, Wapare, Warangi and Wandengereko were not involved in livestock keeping. Thirdly, high prevalence of tsetse flies affects animal health in the district. There are also conflicts caused by animals entering irrigated fields.

Income is an important indicator to measure the individual standard of living. Paddy proved to be the major source of income to the households engaged in both traditional and semi-improved irrigation schemes. The annual mean incomes of paddy recorded in this study were higher than TZS 986576 recorded by Mwatawala et al. (2016) in Mbarali district. Similarly, the income was higher than income reported from the same crop in some African countries. For example, in Ghana, Niger and Zimbabwe, paddy accounts for 40-50\% of the total household income (FAOSTAT, 2006; Chazovachii, 2012). The observed difference could be attributed to the availability of water in the rivers, as this study recorded increases in yield comparing to the previous 10 years. Also, higher mean income could probably be associated with commercialization of paddy, reduced dependence on conventional sources, mainly rein-fed agriculture, due to adverse effects of climate change. According to Wein et al. (1997) in Kissawike (2008), a comparison of income earned from small scale irrigation and that earned from dryland farming or from non-skilled work in Zimbabwe industries revealed that small scale irrigation farmers earned more. 
Table 4. Contribution of paddy to the household income in Iringa and Kilombero districts, Tanzania

\begin{tabular}{|c|c|c|c|c|c|c|c|c|c|c|}
\hline \multirow[t]{2}{*}{ Net income } & \multicolumn{5}{|c|}{$\begin{array}{l}\text { Iringa Rural District } \\
\left(\mathrm{TZS}^{\mathrm{a}}\right)\end{array}$} & \multicolumn{5}{|c|}{$\begin{array}{l}\text { Kilombero District } \\
(\mathrm{TZS})\end{array}$} \\
\hline & $\begin{array}{l}\text { Mlenge } \\
\text { SIS }\end{array}$ & $\begin{array}{l}\text { Mkombozi } \\
\text { TIS }\end{array}$ & $\begin{array}{l}\text { Overall } \\
\text { Iringa }\end{array}$ & USD & $\%$ & $\begin{array}{l}\text { Mkula } \\
\text { SIS }\end{array}$ & $\begin{array}{l}\text { MAKI } \\
\text { TIS }\end{array}$ & $\begin{array}{l}\text { Overall } \\
\text { Kilombero }\end{array}$ & $\mathrm{USD}^{\mathrm{b}}$ & $\%$ \\
\hline Paddy & $\begin{array}{r}1302 \\
200\end{array}$ & 1102300 & $\begin{array}{r}1202 \\
150\end{array}$ & 742 & 80 & $\begin{array}{l}940 \\
199\end{array}$ & $\begin{array}{l}801 \\
980\end{array}$ & 870550 & 537 & 73 \\
\hline Sugarcane & - & - & 0 & 0 & 0 & $\begin{array}{l}220 \\
100\end{array}$ & $\begin{array}{l}137 \\
000\end{array}$ & 178550 & 110 & 15 \\
\hline $\begin{array}{l}\text { Rain-fed } \\
\text { crops }\end{array}$ & 41632 & 27610 & 34621 & 21 & 2 & $\begin{array}{r}42 \\
000\end{array}$ & $\begin{array}{r}23 \\
000\end{array}$ & 32500 & 20 & 3 \\
\hline Off-farm & $\begin{array}{l}170 \\
200\end{array}$ & 108800 & $\begin{array}{l}139 \\
500\end{array}$ & 86 & 9 & 12 & $\begin{array}{r}88 \\
000\end{array}$ & 76000 & 37 & 7 \\
\hline $\begin{array}{l}\text { Forest } \\
\text { products }\end{array}$ & 21881 & 59000 & 40441 & 25 & 3 & 0 & $\begin{array}{r}32 \\
000\end{array}$ & 16000 & 10 & 1 \\
\hline Livestock & 36000 & 43000 & 39500 & 24 & 3 & 0 & $\begin{array}{r}25 \\
000\end{array}$ & 12500 & 8 & 1 \\
\hline Horticultural & 2400 & 7900 & 3950 & 1 & 1 & 1100 & 3200 & 1600 & & 0 \\
\hline $\begin{array}{l}\text { Other } \\
\text { sources }\end{array}$ & 39,123 & 31,400 & 35,262 & 22 & 2 & 0 & 0 & 0 & 0 & 0 \\
\hline $\begin{array}{l}\text { Total } \\
\text { Income/HD }\end{array}$ & $\begin{array}{r}1613 \\
436 \\
\end{array}$ & 1380010 & $\begin{array}{r}1495 \\
424 \\
\end{array}$ & 921 & 100 & $\begin{array}{r}1203 \\
411 \\
\end{array}$ & $\begin{array}{r}1110 \\
180 \\
\end{array}$ & 1187700 & 722 & 100 \\
\hline
\end{tabular}

SIS=Semi-improved scheme; TIS= Traditional Irrigation scheme, HD=Household, other income sources (labour, land rented)

${ }^{\mathrm{a}}$ Tanzanian Shillings; ${ }^{\mathrm{b}}$ US\$ 1 = TZS 1620

Source: Survey Data (2013)

Notwithstanding the higher contribution of paddy to household income, where and when to sell paddy proved to be important in determining the amount of money earned from paddy. This study found that farmers had main three channels to sell their paddy: as husk rice on the farm or off farm, as polished rice at post-harvest centres, and as polished rice elsewhere outside the village. And marketing was guided by market forces. In most cases, agreements were made between farmers and buyers, and male farmers were in charge of marketing, reflecting their dominancy in selling process and income (Mosha and Lyimo-Macha, 2013). A good proportion of farmers in the study areas marketed paddy at farm gate price, and the reason behind this was that they wanted cash to repay back loans of production costs as well as fulfil their immediate household basic needs. Moreover, they sold at low price due to the fact that they were not organized collectively to demand reasonable price. Lack of collective 
arrangement creates opportunity to the business men as they take this advantage to maximize their profit. Businessmen often set any price they fancy and come with their own empty bags, invariably much bigger in size than the normal bags. When these bags are filled with rice, they may weigh about $126-140 \mathrm{~kg}$, far above the normal agreed weight of $100 \mathrm{~kg}$ (FGD, Mkula village, 2014). Poor farmers and disadvantaged groups such as women and elderly found harder to sell their produce as processed rice, retaining or storing for better prices. At harvest times, prices are generally low (farm gate price of TZS 50000 per $126 \mathrm{~kg}$ ), because of high supply in the market. This is contrary to off season times (December-February) when crop prices rise to TZS 120000 per $126 \mathrm{~kg}$. This finding is broadly concordant with those of NBS (2008), Kissawike (2008) and Bjoenlund et al. (2016) who echoed similar trends-low paddy price during harvesting period.

Referring to Table 5, the mean paddy income $\mathrm{ha}^{-1}$ of traditional and in semi-improved FMISs were significantly different $(\mathrm{p}=0.016)$ in the two study cases in Iringa district only. These differences were explained not only by the status of water availability, but also by other factors including variation in soil fertility, farm location, and use of inputs. For example, one of the key informants narrated that "... relatively large and newly cultivated fields ensure higher crop productivity in Mlenge and Mkombozi schemes". He further added... "the incidence of white flies in our farms has negative effects on growth performance of paddy in its early stages", which has a direct impact on crop yield. Records revealed that, in Kilombero District, $88 \%$ of farmers were using inorganic fertilizers such as Diammonium phosphate (DAP) and Urea at the rate of $250 \mathrm{~kg}$ ha-1 whereas in Iringa Rural district only $23 \%$ of farmers used Urea at a rate of $125 \mathrm{~kg}$ ha- 1 . The low use of inorganic fertilizer in Iringa Rural was related to the perceived relatively high soil fertility due to the land being virgin. However, farmers said that to be successful they needed better knowledge on the use of fertilizers, technical skills and/or access to water.

Table 5. Income (per ha) differences between farm households in the traditional and semi-improved FMISs in Kilombero and Iringa districts (2013)

\begin{tabular}{|c|c|c|c|c|c|}
\hline \multicolumn{6}{|l|}{ Kilombero District } \\
\hline Variable & No of cases & Mean & SD & t- value & p-value \\
\hline $\begin{array}{l}\text { Mkula Semi-Improved } \\
\text { FMIS }\end{array}$ & 32 & $\begin{array}{l}601 \\
250.90 \\
\end{array}$ & 206020.39 & 1.643 & $0.51^{\mathrm{ns}}$ \\
\hline MAKI Traditional FMIS & 30 & $\begin{array}{l}587 \\
301.25 \\
\end{array}$ & 111670.53 & & \\
\hline \multicolumn{6}{|l|}{ Iringa Rural District } \\
\hline Variables & No of cases & Mean & SD & t- value & p-value \\
\hline $\begin{array}{l}\text { Mlenge Semi-Improved } \\
\text { FMIS }\end{array}$ & 50 & $\begin{array}{l}988 \\
102.30\end{array}$ & 221950.65 & 2.409 & $0.016 * *$ \\
\hline $\begin{array}{ll}\text { Mkombozi } & \text { Traditional } \\
\text { FMIS } & \end{array}$ & 60 & $\begin{array}{l}671 \\
455.10\end{array}$ & 199210.13 & & \\
\hline
\end{tabular}

** Statistically significant at $5 \%$ and $\mathrm{ns}=$ Not statistically significant 


\subsection{Socio-economic determinants of paddy yield and household incomes in the study areas}

Multiple linear regression models were appropriate to determine influence of independent variables (socio-economic factors) on paddy yield and household income separately. The multiple linear regression model is relevant because dependent variables comprise continuous variables which are not uniformly distributed (Agresti and Finlay, 2009). Referring to Table 6 , the regression model shows that the $\mathrm{R}^{2}$ (coefficient of determination) value was 0.593 . The independent variables (X) investigated were: household head's age; sex of household head; actual schooling years of household heads; household size; percentage of household farm land allocated to paddy production; access to irrigation water; and use of fertilizer in paddy production, farm implements and farming experience. In the second model, $\mathrm{R}^{2}$ was 0.607 and $\mathrm{p}=0.000$. This model used total household income as its dependent variable, and almost a common set of independent variables, with an additional of number of livelihood strategies adopted (Table 7). The coefficients of determination imply that the independent variables accounted for $59 \%$ and $60 \%$ of variation in the dependent variable for yields and income respectively. Explanation of the overall output from the models focused on: p-values for testing the significance of the effect; coefficients for measuring the directions of yield and income levels, and the value for individual coefficients, indicated by positive and negative signs. A positive sign associated with an indication of a coefficient variable increase the probability of increasing yield and household income and vice versa. Regarding the multiple regression outputs, there was a lot of consistency where four variables out of the yield repressors (Table 6) and five out of the income repressors appeared to be statistically significant (Table 7).

Percentage of household farm land allocated to paddy production had a positive influence on the yield and on the income of paddy farmers. This relationship was significant at the level of $\mathrm{p}<0.01$. An average irrigated plot size varied from 0.3 to 0.8 ha in Kilombero and from 1.2 to 1.9 ha in Iringa rural district (Table 2). This means that more land ownership results in increased income. Small size of irrigated plots effectively prevents farmers in Kilombero from transforming from subsistence to commercialization. This finding is in line with findings by Ibrahimu et al. (2013) in their study in Malaysia who reported that having small plot sizes in irrigation scheme means that farmers have to depend on several other activities in order to earn extra income.

Access to adequate irrigation water had positive and significant influence on paddy yield and income at the level of $\mathrm{p}<0.05$. This relationship explains that access to adequate irrigation water or good controllability of irrigation water in the paddy field is more likely to increase paddy productivity by 0.179 units and household income by 0.763 units, holding other factors constant. This implies that farmers who had good access or good controllability to irrigation water in their paddy fields were more likely to harvest more yields, which in turn enabled them to earn more income. The findings are in line with findings of other researchers elsewhere who reported that accessibility to water for irrigation is a paramount determinant of irrigation farming (Defoer, 2003; Kisawike, 2008; Masadeh, 2012)

Furthermore, the study results presented in Table 6 indicate that the use of mechanized farm 
implements in tillage in particular had significant and positive influence on paddy yield per ha. High level of mechanization often enables farmers to cultivate and manage their farms at right time which may lead to successful agricultural production, processing and value addition. During the field survey, a number of power tillers, tractors and ox-ploughs were used in land preparation and harvesting in Mlenge and Mkombozi schemes. Farmers reported, for example, that uses of power tillers, tractors and ox-ploughs increased production efficiency and boosted household income. This means that farmers' ability to produce in bulk is highly related to the ability to utilize mechanized farm implements in the production process. Based on this fact, irrigation agricultural development can be obtained through application of farm mechanization. This observation is supported by Davis et al. (2007) who argued that access to farm mechanization is very important if households are to get out of food insecurity and poverty.

Table 6. The socio-economic determinants of paddy yield/ha in Kilombero and Iringa Districts

\begin{tabular}{lllll}
\hline Variable & Coefficients & Std. Error & Wald & Sig. \\
\hline Constant & 5.391 & 1.243 & & 0.005 \\
$\begin{array}{l}\text { Household head's age } \\
\text { Sex of household heads }\end{array}$ & 0.008 & 0.013 & 0.385 & 0.514 \\
$\begin{array}{l}\text { Actual school years of } \\
\text { household heads }\end{array}$ & 0.029 & 0.048 & 0.062 & 0.630 \\
$\begin{array}{l}\text { Household size } \\
\text { \% of household farm land }\end{array}$ & 0.148 & 0.535 & -0.169 & 0.289 \\
$\begin{array}{l}\text { allocated to paddy } \\
\text { production }\end{array}$ & 0.166 & 0.027 & 0.216 & 0.059 \\
$\begin{array}{l}\text { Access to irrigation water } \\
\text { Use of fertilizer in paddy }\end{array}$ & 0.179 & 0.324 & 0.628 & $0.000^{* * *}$ \\
production & 0.978 & 0.021 & 0.338 & $0.000^{* * *}$ \\
$\begin{array}{l}\text { Farm implements } \\
\text { Farming experience }\end{array}$ & 0.229 & 0.036 & 0.317 & 0.800 \\
\hline
\end{tabular}

$\mathrm{R}$ squared $=0.593 ; *$ statistically significant at $5 \%($ or $\mathrm{p}<0.05)$ 
Table 7. Socio-economic determinants of the household income in Iringa Rural and Kilombero districts, Tanzania

\begin{tabular}{lllll}
\hline Variable & Coefficients & Std. Error & Wald & Sig. \\
\hline Constant & 3.019 & 0.220 & & 0.001 \\
Household head's age & 0.007 & 0.044 & 1.007 & $0.000^{*}$ \\
Sex of household heads & 0.035 & 0.906 & 1.036 & 0.600 \\
School years of household & -0.748 & 0.252 & -0.216 & 0.059 \\
heads & & & & \\
Household farm size & 0.185 & 0.011 & 0.255 & $0.033^{*}$ \\
Household size & 1.183 & 0.273 & 0.580 & $0.000^{*}$ \\
Access to irrigation water & 0.763 & 0.314 & 5.912 & $0.015^{*}$ \\
Use of fertilizer & 0.040 & 0.004 & 0.069 & 0.203 \\
Farming experience & 0.231 & 0.365 & 5.337 & 0.021 \\
Number of livelihood & -3.579 & 0.710 & 25.426 & -3.579 \\
strategies adopted & & & & \\
\hline R squard & & &
\end{tabular}

$\mathrm{R}$ squared $=0.607 ; *$ statistically significant at $5 \%($ or $\mathrm{p}<0.05)$

On the other hand, household head's age had a positive and statistically significant influence on total household income in the study districts. This indicates that chances of smallholder irrigators to produce more paddy increase with age by 0.007 units. In addition, findings from discussions showed that adult irrigators and those who were married were in better positions to earn more income than youth or single household heads. This could be attributed to the fact that older irrigators are more experienced in farming than youth.

Similar results were reported during focus group discussions. For example, one of the participants in the Mkombozi irrigation scheme asserted that "...older farmers are consciousness about advantages of farming and are more experienced with irrigated agriculture ... have a broad mix of agronomic, irrigation and business skills compared to youths. It was revealed that youth in the rural areas appear to lack necessary skills and experiences to boost agricultural development, including irrigation farming. This was particularly manifested in the discussions with village and irrigation association leaders, where members blamed the district council officials for not providing education and extension services to the youth who are the majority of the population in the study areas. The result is in agreement with a finding by Ley et al. (2012) who reported that youth irrigators require training in agronomic practices, business skills and operation and maintenance of irrigation infrastructure as they are less experienced than older farmers. This could be because of better understanding and experience of downs and ups in fulfilment of certain basic human needs as well as social obligations. The experience acquired also transformed into self-confidence which made them good risk takers, consequently making older irrigators more autonomous than those who had just entered agricultural sector. According to Urassa (2015), a decline in state-funded extension services and training, and input subsidies has created problems to farmers, and obtaining appropriate inputs has been 
identified as a major obstacle to productivity in countless regions of Tanzania as elsewhere worldwide. In Tanzania, the adoption of new irrigation technologies and practices has been limited by a range of social and economic issues, especially for marginalized households including women and children household heads, and labour-deficient households (Mdemu et al., 2017).

On the other hand, farming experience had a positive and statistically significant influence on paddy production level (Table 6). The result implies that as one's experience in irrigated agriculture increases by one unit, paddy yield level increases by 0.026 unit These results resemble those of Tenge et al. (2015) who found that when a farmer has good experience in irrigation farming, he/she is likely to produce more than inexperienced ones.

The study results in Table 7 further show that household size had positive influence on total household income. Study observations indicate that family labour is one of the important agricultural inputs in paddy production in the irrigation scheme. This implicitly means that a household with more number of adult members is more likely to have more advantage. They may generate more agricultural produce and ultimately achieve higher household income compared to ones with fewer members. Similar results were reported by Quasem (2001) that households with a large number of adult members can devote more time for agricultural production, which in most cases results in higher yields and incomes.

Fertilizer is also a very important factor associated with higher yields. This result rejects expectation as the amount of fertilizer applied showed a positive, but not significant effect on yield. This may reflect the effect of few proportions (32\%) of farm households which utilized fertilizer and for those who did not; their application rate ratio was small as 1:3 of the recommended rate. Although farmers in Kilombero district had lower income than those of the Iringa district, they still appeared to appreciate the contribution of irrigation scheme. This was evidenced by one focus group discussion meeting where it was agreed that ... "Although what we get is very little, it is better to cultivate in the scheme than to depend totally on rain-fed agriculture (Mkula, FGD). The remark reflects the economic value that irrigated paddy holds to livelihood improvement. It provides food for home consumption, employment for landless people and for basic human needs. It was emphasized that the income accrued from paddy selling was used to pay for education and health services, purchasing household assets and house construction or improvement. The findings conform to those of FAO (2008), You et al. (2010) and Ley et al. (2012) which asserted that irrigation has a great contribution to household incomes and welfare in many Africa countries.

\section{Conclusion}

This study has illustrated that paddy is a source of livelihood to the majority of respondents in the four FMISs in the study districts because it serves as both food for home consumption and a source of cash. It also revealed that a significant proportion of the canals remained unlined, which is causing water loss through high rate of infiltration, a delay in conveying water to plants, which actual limits a wide and long delivery to water to the downstream fields. Despite these drawbacks, the study revealed that both traditional and semi-improved irrigation schemes provide substantial paddy yields per ha, which in turn contribute more to 
overall annual household income than any other livelihood activity in the study areas. Low income from rain-fed crops in Iringa district in particular was a result of a prolonged drought period. Irrigation therefore becomes the main rescuer of people from food and income poverty in the areas and is the foremost thing in the irrigators' minds. However, to improve the popularity of paddy as household food and income security among smallholder irrigators, there is a need for better irrigation systems, adoption of recommended agronomic practices that will boost paddy productivity and hence income security. The study argues that access to adequate irrigation water is the most fundamental factor, but it is limited by poor irrigation infrastructures. Besides, improvement of irrigation schemes needs government and development partner hands in terms of financial support as farmers alone cannot afford it because of high costs associated with construction of irrigation systems. Regression of paddy yield and income on their determinants showed that households that utilized improved farm mechanizations (tractor, power tiller and oxen plough) had higher yields than those which did not utilize them. The use of farm mechanization enhances a thoroughly soil and organic matter mingling situation. It improves not only the production efficiency in farming but also mass production, and hence increases income from irrigated crops.

\section{Recommendations}

Since poor irrigation infrastructure system has been revealed as one of the fundamental challenges in FMIS, improving irrigation systems might double the yield of paddy and contribute significantly to food and income security of the farming communities. In this view, it is recommended that efforts should be made by the Ministry of Agriculture and Food Security to come up with short and long term strategies to secure funds for irrigation infrastructural development, and this should be part and parcel of long term national plans for food security improvement and poverty reduction.

It is also recommended that the government, through district councils, should provide technical and financial support that farmers can access in order to use farming machinery. It is anticipated that this will improve paddy productivity with growing good market prices which could boost income and food availability of marginalized households in rural areas.

\section{Acknowledgements}

We are grateful to the Tanzania-Norway Enhancing Pro-Poor Innovations in Natural Resources and Agricultural Value Chains (EPINAV) Programme for financial support of the study from which this paper is based. Furthermore, logistical support from all individuals during fieldwork is highly appreciated. We also acknowledge anonymous reviewers, whose critical views helped in improving the quality of this article. 


\section{References}

Adams, W.M., Potkanski, T.L.G, \& Sutton, L.G. (1994). Indigenous Farmer-Managed Irrigation in Sonjo, Tanzania. The Geographical Journal, 160 (1): 17-32.

http://projects.nri.org/waterlaw/Documents/Maganga_pce

AWM (2010). Agricultural Water Management National Situation Analysis Brief. http://awm/solutions.iwmi.org/Data/Sites/3 Bjornlund, H., van Rooyen, A \& Stirzaker, R. (2016). Profitability and productivity barriers and opportunities in small-scale irrigation schemes, International Journal of Water Resources Development,

DOI: $10.1080 / 07900627.2016 .1263552$

Chazovachii, B. (2012). The impact of small scale irrigation schemes on rural livelihoods: The case of Panganai irrigation scheme Bikita District Zimbwabwe. Journal of Sustainable Development in Africa, 14 (4): 217-231.

http://www.arpnjournals.com/jabs/research_papers/rp

Creswell, J.W. (2014). Research Design: Qualitative and Mixed Methods approaches. (2ed). Colifornia Sage Publication Inc.246pp.

Defoer, T. 2003. Rice Based Production System for Food Security and Poverty Alleviation in sub-Saharan Africa, In Proc. $20^{\text {th }}$ Session of the International Rice Commission.

Fanadzo, M., Chiduza C, \& Mnkeni, N.S. (2010). Overview of smallholder irrigation schemes in South Africa: Relationship between farmer crop management practices and performance. African Journal of Agricultural Research, 5 (25): 3514-3523.

http://www.academicjournals.org/journal/AJAR/

Fanadzo, M. (2012). Revitalisation of smallholder irrigation schemes for poverty alleviation and household food security in South Africa: A review. African Journal of Agricultural Research: 7(13): 1956-1969. http://scholar.google.com/citations?user

FAOSTAT (2006). FAO Statistical Database. http:www.fao.org/faostat/

FAO (Food and Agriculture Organization of the United Nations) (ed.). 2008. Water and the Rural Poor: Interventions for improving livelihoods in Sub-Saharan Africa. Rome.

Iringa District Council Profile (2013). Iringa Rural District Socio-Economic Profile. Iringa District Council. 15pp.

Kadigi, R., Mdoe, N. \& Ashimogo, G. (2007). Understanding poverty through the eyes of the poor: The case of Usangu Plains in Tanzania, Physics and Chemistry of the Earth 32 (15-18), $1330-1338$.

Kilombero District Council. (2013) Kilombero District Socio-economic Profile. Kilombero, Morogoro. 10pp.

Kissawike, K. (2008). Irrigation-based Livelihood Challenges and Opportunities: A gender technographic study of irrigation development intervention in the Lower Moshi Irrigation Scheme in Tanzania, Doctorate dissertation, Wageningen University pp. 235 
http://edepot.wur.nl/122016.

Ley, G. J, R., Tenge, A.J, \& Ravoavison, G. (2012). Integrated Management Options for Sustainable Lowland rice-legumes Cropping System. Research Report for ASARECA. Entebbe. http://www.asareca.org.

Mdemu, M. V., Mziray, N., Bjornlund, H. \& Kashaigili, J. J. (2017). Barriers to and opportunities for improving productivity and profitability of the Kiwere and Magozi irrigation schemes in Tanzania, International Journal of Water Resources Development, 33:5, 725-739, DOI: 10.1080/07900627.2016.1188267

Masadeh, M.A. (2012). Focus Group: reviews and practices. International Journal of Applied Science and Technology 2(10): 63-68.

http://scholar.google.com/citations?user=Aujl-PMAAAAJ\&hl=en

Minow P (1997). Thai Rice under Royal Patronage, Thailand ${ }^{\text {ee }}$ rice export.

[http://www.thairice.org/eng/aboutRice/rice_trade_3.htm]. Accessed on 20/2/2018.

MNRT (2015). S. (2004). "Stabilization of commodity market of interest to Africa. Paper National Forest Resources Monitoring and Assessment of Tanzania Mainland (NAFORMA)", Main results. 106pp.

Mongkolsmai, D and Rosegrant, M. W (1995). "The Impact of Irrigation on Seasonal food Availability, Farm Income and Labor Demand in Thailand", prepared for IFPRI/FAO/AID

Workshop on Seasonal Causes of Household food Insecurity, Policy Implications and Research Needs, December 10-13, 1995, Annapolis Maryland, U.S.A.

Mosha, D. B. and Lyimo-Macha, J. G (2013). Improved Dairy Goats Farming in Transforming Gender relations among agro-pastoral Societies in Kongwa and Mvomero Districts, Tanzania. Journal of Continuing Education and Extension 4 (2): 377-395.

Mosha, D.B., Vedeld, P., Kajembe, G.C., Tarimo, A.K. P. R. \& Katani, J. Z., (2016). "Reflections on evolving water management institutions and institutional bricolage: a case of irrigation schemes in Iringa Rural and Kilombero districts, Tanzania", Water Policy 18: 143-160.

National Bureau of Statistics (NBS) (2008). "National Sample Census of Agriculture Report", NBS, Dar es Salaam, Tanzania.

NBS, (2013). 2012 population and housing census population distribution by administrative areas. NBS, Dar es salaam, Tanzania. 244pp.

Pallant, J. (2007). SPSS Survival Manual. A step by step guide to data analysis using SPSS for windows (3rd edition). Open University press, England SL 2QL.336pp.

Quasem, Md. A. (2001). "Irrigation and Household Income: A case study of Bangladesh.

Bangladesh J. Agric. Economics", XVII. 1 \& 2: 61 -83.

http://ageconsearch.umn.edu/bitstream/202690/2/Resear 
Sinyolo, S., Mudhara, M, \& Wale, E. (2014). "The impact of smallholder irrigation on household welfare". The case of Tugela Ferry irrigation scheme in KwaZulu- Natal, South Africa. Water SA, 40: 145-156. http://www.ajol.info/index.php/wsa/article/view/105718

Tenge, A. J., Mvuma, M., Bakar, A. N., Mongi, S. B., Mwakijele, H. J., \& Gabriel, M. C. (2015). "Community Perception on Lake Victoria Basin Resources Degradation: Implications to Sustainable Management”. Journal of Sustainable Development, 8(2):14-25.

http://wp.auburn.edu/sfws/sfwsdirectory/faculty-directory/zhang-yaoqi/

Urassa, J. K. (2015). "Factors influencing maize crop production at household levels": A case of Rukwa Region in the Southern highlands of Tanzania". African Journal of Agricultural Research 10(10), 1097-1106.

United Republic of Tanzania (URT) (2010). “The National Irrigation Policy”. Ministry of Water and Irrigation, Dar es Salaam. 70 pp.

URT (2011). "Water Sector Status Report 2011 with a summary of water sector progress since 2007”. Ministry of Water, Dar es salaam, Tanzania. 102pp.

URT (2012). Division of Environment, Office of the Vice-President. National Strategy for

Reduced Emissions from Deforestation and Forest Degradation (REDD+). Dar es Salaam, Tanzania.

URT (2013). "Water Sector Development Programme". Ministry of Water, Dar es salaam, Tanzania. 102pp.

Wim V. Av. (2012). "Performance of Smallholder Irrigation Schemes in the Vhembe District of South Africa, Problems, Perspectives and Challenges of Agricultural Water Management", Dr. Manish Kumar (Ed.), ISBN: 978-953-51-0117-8, In Tech.

http://www.intechopen.com/books/problems-perspectivesand-challenges-of-agricultural-wate r-management.

You, L., Ringler C., Nelson G., Wood-Sichra., U, Robertson, R., Wood, S., Guo, Z, Zhu, T, \& Sun, Y. (2010). "What is the Irrigation Potential for Africa? "A Combined Biophysical and Socio-e economic Approach. IFPRI Discussion Paper 00993. International Food Policy Research Institute, Washington, D.C.

http://www.gdn.int/admin/files/SSA_4_PolicyBrief_Irrigation

\section{Copyright Disclaimer}

Copyright for this article is retained by the author(s), with first publication rights granted to the journal.

This is an open-access article distributed under the terms and conditions of the Creative Commons Attribution license (http://creativecommons.org/licenses/by/4.0/). 